\title{
Journalism education and training in Malawi: A case for a national policy
}

Levi Zeleza Manda

Director, Development Media Consulting, Blantyre, Malawi.Email: mandalevi1@gmail.com

\begin{abstract}
Based principally on verbal data collected through interviews with journalists, journalism educationists, journalist trainers, and curriculum analysis, this study notes some progress made in the field of Malawian journalism since independence. However, it argues that despite the welcome increase in the number of journalism and communication qualifications offered by public and private journalism training colleges in Malawi, the quality of the output is still lackluster. This is overwhelmingly because practical skills courses are taught inadequately, haphazardly and theoretically due, partly, to inadequate human and material resources and lack of a national policy to guide the formation of journalists. It recommends that to improve the quality and relevance of journalistic output, Malawi should draft and publish a journalism education and training policy to guide all journalism training colleges. It also recommends that training colleges should partner with the industry, multilateral organizations with interest in communication and media development, government departments and NGOs not only for industrial attachment but also for these to sponsor communication and journalism training programmes. Partner institutions should consider procuring training materials and assets for the training institutions. The study further recommends that partner institutions need to consider sponsoring academic staff for higher education in journalism and media studies.
\end{abstract}

Keywords: journalism training, journalism education and training policy, media content, media, media development, Malawi

https://dx.doi.org/10.4314/jdcs.v5i2.3

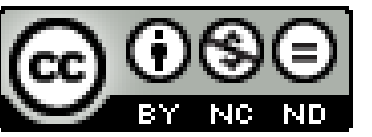

(C) 2018. The Author. This work is licensed under the Creative Commons Attribution 4.0 International License (CC-By-NC-ND). Users may freely share and redistribute this work provided that the author and the Journal of Development and Communication Studies are fully acknowledged. Users may not tweak or remix and offer this work for sale. The full license may be accessed at https://creativecommons.org/licenses/by-nc-nd/4.0/

\section{Introduction}

Since Malawi reverted to multiparty politics in 1994, the number of radio and television stations has increased exponentially. As Table 1 illustrates, by June 2015 the Malawi Communications Regulatory Authority (MACRA) had licensed 77 broadcasters; of which, 39 radio stations and 11 television stations were operational. This means that in 20 nears, the radio and TV industry had 
experienced a 3900 and 1100 percent growth respectively over the 1964-1994 period, when there was only one public radio station. Although these radio and TV stations are technically classified as public, private, and community (MACRA, 2015), there is no significant difference in their commercial and programming logic. The most obvious and, perhaps, the only distinguishing criterion is that community radio coverage is limited to a radius of 100 kilometres. Except in the case of the Malawi Institute of Journalism (MIJ) Radio (see Ifex, 2002), the Malawi Communications Regulatory Authority has not exercised its authority as provided by Sec. 51,3 (ab) of the Malawi Communication Act (Malawi Government, 1998) to legally prevent community radio stations from running commercials, broadcasting news, and covering elections. This power has been removed from the revised Communication Act of 2016 (Malawi Government, 2016).

The newspaper industry, which had been the major source of alternative political discourse in the early 1990s, shrunk from 21 newspapers to just two dailies (The Daily Times and The Nation) and four weeklies (Malawi News, Sunday Times, Weekend Nation and Sunday Nation) by 2015 and so did the number of newspaper publishers. Only two leading companies, Times Group Limited and Nation Newspapers Limited, publish the above newspapers. The magazine publication landscape has not changed much. The popular Moni magazine closed shop after publishing for nearly five decades. The quarterly Pride Magazine now comes out irregularly, an indication that perhaps something ominous had befallen the glossy investigative news magazine. Presently, the most reliable news magazines are the Lamp and Together, both published monthly by Montfort Media, a Catholic Church outfit that also publishes the fortnightly ChiChechwa language Mkwaso newspaper.

Despite this dearth of newspaper and magazine publications, there is a remarkable growth in online news publishing, with http://nyasatimes.com, http://Malawi24.com, http://banthutimes.com, http://malawivoice.com, http://maravipost.com and http://malawiindependentblog.com as the most regularly accessed. This could be an indication that financial constraints could be responsible for the death of the print media. Online publications are easier and cheaper to establish sine they mostly require modifying existing templates such as those by http://wordpress.com.

As the Institute for War and Peace Reporting election campaign media monitoring project indicated in 2014, online news sites and social media (notably http://facebook.com and to a less extent http://twitter.com) upstaged traditional media and proved to be a major source of election news and a platform for unfettered political debate on the 2014 elections (IPWR, 2014).

Table 1: Licensed broadcasters in Malawi

\begin{tabular}{|l|l|l|l|l|l|l|}
\hline 1995-2015 & $\begin{array}{l}\text { Licensed } \\
\text { N= }\end{array}$ & Public & $\begin{array}{l}\text { Commerci } \\
\text { al/private } \\
\text { /commun } \\
\text { ity }\end{array}$ & $\begin{array}{l}\text { Total } \\
\text { Operational } \\
\text { N= }\end{array}$ & $\begin{array}{l}\text { Increase } \\
\text { over 1964- } \\
1994 \\
\text { period }\end{array}$ & $\%$ \\
\hline TV & $\mathbf{2 5}$ & 1 & 24 & $\mathbf{1 1}$ & $\mathbf{1 - 1 1}$ & $\mathbf{1 1 0 0}$ \\
\hline Radio & $\mathbf{5 2}$ & 2 & 50 & $\mathbf{3 9}$ & $\mathbf{1 - 3 9}$ & $\mathbf{3 9 0 0}$ \\
\hline $\begin{array}{l}\text { Grand } \\
\text { Total }\end{array}$ & $\mathbf{7 7}$ & $\mathbf{3}$ & $\mathbf{7 4}$ & $\mathbf{5 0}$ & $\mathbf{1 - 5 0}$ & $\mathbf{5 0 0 0}$ \\
\hline
\end{tabular}

Source: Based on Malawi Communication Regulatory Authority (MACRA) licence data, 2015

Manda and Kufaine (2013) note that there are today more college trained journalists in Malawi than there were before 1994 owing, partly, to the professional training courses offered in the country and progressive legislation that has allowed the establishment of media houses. The 
Malawi Worlds of Journalism Study indicates that the majority of Malawian journalists are likely to hold a professional post-secondary school diploma or degree in journalism or communication studies and vow to stick to the ethics and standards of journalism (see Manda, Nyirenda and Tsitsi, 2017). The WJS survey also concludes that the majority of Malawian journalists view themselves as champions of social change and national development, educators and informers of the people but not messengers of politicians. However, this rise in journalists with diplomas and degrees does not seem to have been matched with an increase in product quality to "make a real impact on society" as Berger and Matras, (2007, p. 31) recommend. Follow up stories and sustained investigations of issues are rare and spasmodic. Fake, concocted and defamatory stories by anonymous journalists on online news pages are frequent. Newspapers, radio and TV apologies for misrepresentation and misquotation of sources are not uncommon; which is a sign of a job not thoroughly done.

To explain why there is lacklustre journalism performance in Malawi, this paper gives a historical context, which defines media and journalism development, education, training and practice in Malawi before analysing teaching staff and curriculum challenges. It closes with recommendations for improvements in journalism education and training in Malawi.

\section{Historical context}

The development of the Malawian media and journalism is strongly linked to the country's political evolution. Four distinct periods can be delineated: the colonial period (1891-1964); the independence/MCP Period (1964-1992); the Transitional Period (1992-1994) and the posttransition or the multiparty democracy period (1994 to 2015 and beyond).

The colonial period: 1891-1964

Ross (1996) writes that Malawi became a British protectorate in 1891 largely following recommendations by settler businesses, consuls and Christians who wanted to stop the slave trade and replace it with acceptable trade and commerce in Nyasaland and to stop Portuguese expansionism from present day Mozambique. Very little is known about the media during this period. In his history seminar paper, Sembereka (1980) writes that the early missionaries-cumgovernment had two major journals, Life and Work in British Central Africa and the Central African Planter. The Central African Planter changed its name in 1897 and became, the Central African Times in 1897, later the Nyasaland Times and finally the Daily Times when it was bought by Dr Hastings Kamuzu Banda (Hall and Ham, 1994; Chitsulo and Mang'anda, 2011). Life and Work in British Central Africa was a missionary magazine which politically supported African people's rights and freedoms, while the Central African Planter mostly served European planters' interests and was often at loggerheads with the rival Life and Work. The Central African Planter was more of a business paper owned by the Chamber of Agriculture (later Chamber of Commerce and currently Malawi Confederation of Chambers of Commerce) and thus reported on economic trends in the protectorate, especially in relation to agriculture. With the emergence of agricultural research from around 1905 and 1907, and the establishment of the Department of Agriculture in 1909 (see Kabuye and Mhango, 2006), the Central African Planter disseminated research findings on the protectorate's main cash crops, especially coffee and cotton, and later, tobacco and tea. Agricultural research rapidly expanded from 1945 with the establishment of the Colonial Development Corporation (CDC), now Malawi Development Corporation (CDC). New research stations were established in the protectorate between that time and the late 1950s. Good examples of these were the Mimosa Tea Research Station in Mulanje district established in 1951 and the Chitedze Research Station in Lilongwe, also established in the 1950s. Initially the Chitedze Research station was named after Geoffrey Francis Taylor Colby, who is regarded as Nyasaland's most developmental governor. The colonial media systematically communicated agricultural research done by these institutions. 
In addition to the above publications, the Blantyre Mission had its own journal, Kalilole the Mirror), written in ChiMang'anja (the language of the Mang'anja) the dominant ethno-linguistic group in the areas now called Blantyre and Zomba. Kalilole was not only meant to deepen the religious education of the African who had converted to Christianity but also advocated a certain measure of African freedom. In current-day media classification, Life and Work in British Central Africa, the Central African Planter, and Kalilole would thus be described as private publications.

The colonial administration had its own newspaper, the British Central Africa Gazette, which espoused and promoted the views of the British Empire. After independence, The British Central Africa Gazette became the (Malawi) Government Gazette. The other best-known newspaper of the time, Vyaro na Vyaro (Here and Beyond), was run by the Livingstonia Mission, another Scottish mission, and was thus a sister paper to Life and Work, targeted at the mission-educated audiences in the northern parts of Malawi. Very little is known about who edited these publications and what training the editors and 'journalists' had.

A literature search for this study failed to locate any information about journalism training in Malawi from 1891 to 1964 but, it is likely that white missionaries and their converts, government officers and civil servants were responsible for editorial decisions, even though they might not have had any formal journalism training.

The nationalist period, 1944 to 1964, saw the emergence of a number of newspapers and magazines that carried nationalist propaganda. These included Zoona (the Truth), Zatsopano (the Current or New), and Mbadwa (the Citizen). These were meant to articulate the African nationalist sentiments, often in a highly propagandistic manner.

The turning point in the nationalist media was in 1959 when Malawi Congress Party's Aleke Banda founded and edited an "aggressive, widely circulated" pro-nationalist and proindependence biweekly, and later weekly paper, the Malawi News (Rotberg, 2002, p.33) which exists to date as part of Dr Banda's media empire. By their nature, the nationalist media did not bother about investigative skills. They were preoccupied with politics, race relations, and the issues of social and economic welfare within the colonial contexts; issues which could be easily written on in a non-journalistic style.

\section{The Independence period: 1964-1992}

This situation did not fundamentally change in the immediate post-colonial period. Malawi's first president, Dr Hastings Kamuzu Banda is on the record as having described journalists as liars and that he hated them (Italiander, 1961). This could explain why from 1964 to 1994 the Malawi government did not invest in local journalism education and training. Like in the colonial period, there was no national journalism education and training policy from 1964 to 1994. Despite the very early establishment of the University of Malawi in 1965, just a year after independence, there was no course in journalism or media studies in the country - just like political science - until Malawi changed to political pluralism through the referendum of June 14, 1993. When individual lecturers in the University of Malawi took chances, they offered journalism as part of Creative Writing, Language and Literature, Discourse Analysis, Sociolinguistics, Drama, and, much later, as part of Theatre for Development. The university graduates who went into journalism were mostly hired to edit the English language and learned journalism through trial and error. Since the journalism of the Banda era did not require critical analysis and investigation, the journalists of the time did not miss formal in-depth journalism education and training. Their reporting and the stories they wrote were almost always about the then governing Malawi Congress Party (MCP), the Ngwazi (as Kamuzu Banda was called) and how Malawi had developed compared to how the colonialists had left it. However, the multiparty era required more journalistic skills needed to interpret and contextualise the new discourses, such as human rights, freedom and liberal economics. 
According to Wimmer and Wolf (2005), the fact that there was no university level training in Malawi did not mean that those who practised journalism did not have alternative opportunities. Actually, those who joined the Malawi Broadcasting Corporation (MBC), the Malawi News Agency (MANA), the Information Department, and the Blantyre Newspapers, were sent for short handson training at the British Broadcasting Corporation (BBC) in the United Kingdom, the Voice of America (VOA) in the United States of America (USA), Deutsche Welle in Germany, Radio France International (RFI) in Paris, the Thomson Foundation and Cardiff University in Wales among other places. Other countries where Malawian journalists trained included Kenya, North Korea and Israel. Nonetheless, such training did not meaningfully change the structures and orientations of the media sector because there was no vision to guide the nation in the area.

The political developments at the time of independence greatly shaped the future course of media development. In 1963, Malawi attained self-government and became independent on 6 July1964 and a republic on the same date in 1966. The euphoria of independence did not last as a few months after independence there was a cabinet crisis over health policy and other issues, including the fast tracking of indigenisation of the civil service. Dr Kamuzu Banda preferred a more gradual change-over but the younger and more militant cabinet ministers, who were in touch with grassroots realities and demands for the "cake of independence" wanted immediate change. Banda fired some ministers while others resigned in solidarity with those fired. A few left the country fearing for their lives. This cabinet crisis had a lot of repercussions on media development because, for his own survival, Dr Banda turned to government publications and his newspapers to castigate and discredit the "quick-change" ministers as "rebels" and inexperienced young men and a woman.

Immediately after this crisis, the Malawi Broadcasting Corporation was established and it immediately came under the control of Dr Banda through his "trustworthy" right-hand minister, the founder of Malawi News, Aleke Banda. Also, after independence, Kamuzu Banda bought the Malawi News and the Daily Times, consolidated them into the Blantyre Newspapers Ltd (BNL), and fully controlled them (Hall and Ham, 1994). The editorial policy of the two newspapers was thus politically determined by Dr Banda, his Minister of Information, or the politically appointed board members of the BNL. The two newspapers thus became mouthpieces of the government and the governing MCP. There was almost no room for creativity for the journalists at the BNL. Thus, they could not systematically investigate topical political, economic, developmental issues apart from what the government and the party regarded as "development". Despite the new dispensation, new constitution and new statutes, the MBC is yet to graduate from its age-old stranglehold by politicians into a real public broadcaster.

Like the colonial period, the independence period did not have a national journalism education and training policy.

\section{The Transition period: 1992-1994}

The media landscape changed considerably between 1992 and 1994. We have called this the "transition period" because it neither belongs to the Malawi Congress Party draconian era nor to the multiparty democracy era. It was a period of fluidity when the Malawi Congress Party was legally in charge of the country but could no longer dictate the pace of events. This was the time people came out in the open to criticise the Banda regime without fear of reprisals. The collapse of the Soviet Union and the political realignment of the NATO countries; the release of the Catholic Bishops Pastoral Letter of 1992; the interventions by the Church of Central Africa Presbyterian (CCAP); the open challenge by and subsequent arrest of the trade unionist Chakufwa Chihana and the joining in of Bakili Muluzi; urban worker protests and demonstrations by students of the University of Malawi, could not go without local and external media attention. Notable was the coverage of political events in Malawi by Channel Africa of the South African Broadcasting Corporation (SABC) and the BBC's Focus on Africa. The former almost daily broadcast taunts by Malawian political exiles such as Kamlepo Kalua, Shyly Kondowe and Unandi Banda causing 
political ferment in the country. Freedom of expression became the catchword; something, not even the once dreaded police and Malawi Youth League and Malawi Young Pioneers could stop.

Suddenly, journalists "of all types" emerged. Newspapers flourished. Some disappeared as fast as they emerged. At one rough count between 1993 and 1994, Malawi had over 20 newspapers but still one radio station (MBC) and no television station (Chitsulo and Mang'anda, 2011; Manjawira and Mitunda, 2011).

Like the publications of the 1944-1964, the focus of the "new" media in the postindependence transition was on the quest for political change. Due partly to lack of training in professional journalism, writers often published articles void of intellectual debates and researchbased accounts. Political opinions were presented as facts in an uncritical manner. The exception was probably the Democrat, the Michiru Sun, and the Nation, which started publishing in 1993. These employed investigative journalism techniques and utilised historical research in unravelling the Banda dictatorship. The three newspapers were unique mainly because the key figures at these papers, Grey Mang'anda, Gaudy Maluza and Edward Chitsulo at the Michiru Sun and late Mapopa Chipeta and late Hardy Nyirenda at the Democrat, Ken Lipenga and Alfred Ntonga at the Nation were university graduates with some exposure to skills in research-based or investigative journalism.

Since then, except for moments of rare brilliance such as the 2013 investigation of Cashgate, as the plunder of public resources at Capital Hill in Lilongwe came to be known, the state of investigative journalism in Malawi can hardly be described as mainstream.

Up to this period, Malawi still had no journalism education and training school and national policy.

\section{The democracy period: 1994-Present}

By 1994, Malawi had three dailies, the Monitor, Nation, and Daily Times and twelve regular weeklies. The most notable weeklies were the Malawi News, the Inquirer, the UDF News, the Democrat, the Herald, the Mirror, the Independent, Michiru Sun, the New Express, the New Voice, the Chronicle, the National Agenda, and the Statesman. With this fast growth of the print media sector, many readers were optimistic that with training, the media in Malawi would develop and professionalise. Indeed, since 1995, the Malawi Institute of Journalism, the Polytechnic, Chancellor College, Blantyre International University, Pentecostal Life University, University of Lilongwe and many nonaccredited and backyard private institutions have offered different types of media-related professional courses, at certificate, diploma, and degree levels. However, despite the plentiful training, most of the pioneer newspapers of the mid-1990s have since folded; some because of litigation, others because their publishers had joined politics or had been employed by politicians, and yet others for lack of media and financial management skills. Interestingly enough, most, if not all, the papers that closed shop were owned by senior and foreign-trained journalists: The Michiru Sun (Grey Mang'anda, Gaudy Maluza and Edward Chitsulo), the Independent (Janet Karim and Felix Mponda), the New Express (Willie Zingani and Felix Mponda), and the Statesman (Kaulanda Nkosi and Bentry Mndhluli). Those publications that lasted were, and still are, mostly owned by politicians or people affiliated to political causes. A report of the 2000 Article 19 study argued that through such newspapers the views of politicians are disseminated as fact and as real news, which may do a disservice to any reader in search of objectivity, in-depth analysis, or facts, which research and research-based reporting may offer. Moreover, when articles are written and published in one paper and picked up, cited or re-run in a paper owned by a fellow party member, the views they carry become more credible and the stories they tell more compelling. When these are reiterated by the Malawi Broadcasting Corporation (MBC) - for example, in its press review programme, they are regarded as fact. In such a situation, robust debate, diversity of opinion, and democracy suffer. In such a reporting culture, journalists and media houses generally may not value much research-based communication or investigative reporting. 


\section{Evolution of media training}

As noted earlier in this paper, Malawi had no formal course in journalism until after the reversion to plural politics in 1993. The first professional courses were provided by KTZ in Mzuzu, Malawi, from 1994. KTZ records indicate that by 1996 it had trained over 200 journalists through short (3 months) courses that concentrated on practical journalism (newswriting, feature writing and ethics of journalism). Some of the graduates of the KTZ rose to prominence and won media awards for their journalism. Despite being hugely patronized, KTZ did not last long because the team members split up and each went to seek employment elsewhere. The income from students could not sustain the directors who doubled as teachers

More comprehensive training was provided by the Malawi Institute of Journalism (MIJ) from 1996. Established in 1995 with funding from the European Union, the MIJ was located at the Polytechnic for strategic reasons: to utilize expertise from the University of Malawi but also to fulfil one of the conditions of using EU assistance - that the Malawi government contributes 10$20 \%$ of the funding. Since its establishment, the MIJ has trained over 2000 fresh school leavers on its certificate and diploma programmes and experienced journalists on its short courses. The exact number of students that have gone through MIJ cannot be authenticated because old files cannot be located (Pasanje, 2008). The MIJ is, however, the largest journalism training institution at certificate level and diploma level, with campuses in Blantyre, Lilongwe and Mzuzu, where it is currently rivalled by the University of Malawi's Polytechnic Continuing Education Centre (CEC). It has a computer lab for Desktop Publishing training and a radio studio for radio production but no specialised TV editing suite for TV journalism. Like the Polytechnic it has no student laboratory newspaper.

\section{University training in journalism}

The Malawi Polytechnic, one of the four constituent colleges of the University of Malawi (with Chancellor College, Kamuzu College of Nursing and College of Medicine) has made its own grand contribution to journalism in Malawi. In the early 1990s, it ran a postgraduate diploma in journalism. This postgraduate diploma was launched before political reforms, during a time University of Malawi and political authorities did not accept the use of the name "journalism" in the programme. So, it had to be named the Post Graduate Diploma in Communication Studies.

The institution also conducted several sponsored and own-generated short courses for journalists before finally launching the Bachelor of Arts in Journalism (BAJ) degree in 1999 when the political atmosphere was conducive.

Currently, this degree training in journalism is rivalled by the Bachelor of Journalism degree course offered by the Blantyre International University and the Bachelor of Business and Organisational Communication offered by the Polytechnic's Department of Language and Communication Studies. At Chancellor College (University of Malawi) Bachelor of Arts (Media for Development), Bachelor of Arts (English) and Bachelor of Arts (Communication and Culture) degree programmes have emerged as parallel or alternative choices for those who intend to join journalism.

The Chancellor College bachelor's degree in Media for Development deserves special mention. As Manyozo reports on his webpage, ${ }^{1}$ the degree programme started in 2005 and is hosted by the Department of Fine and Performing Arts in the Faculty of Humanities. Although claims that it was the first "method-driven and theory based" communication for development training programme in Africa are highly contestable, the fact remains that it was a significant contribution to journalism education and training in Malawi because it filled a gap in the Malawi Polytechnic's BAJ programme, which cursorily taught communication for development ${ }^{2}$. The Chancellor College BA (Media for Development) was the only specialist communication degree course in Malawi that concentrated on communication and media for development until recently when the Lilongwe University of Agriculture and Natural Resources (Luanar) started offering 
bachelor's degrees in agricultural development communication, agricultural education and agricultural extension, and master's and $\mathrm{PhD}$ degrees in rural development and extension.

The other training institutions, such as the Skyway University and Accountancy Tuition College, are private commercial institutions that teach foreign journalism curricula. The most prominent qualification they offer is the ABMA diploma in professional journalism. ${ }^{3}$ However, the oldest distance education centre in Malawi to offer training in journalism is the Aggrey Memorial School which started in 1976/7 but has not expanded. It is worth noting that none of the schools of journalism in Malawi feature on the UNESCO list of Centres of Excellence in journalism education and training, an indictment that Malawi's journalism education and training falls short of the UNESCO assessment criteria (for assessment criteria, see Berger and Matras, 2007). Again, this could be a result of lack of a national journalism education and training policy to guide the training institutions to be creative and be counted internationally.

\section{Methodology}

The study mostly employed a qualitative design and used oral and an unstructured questionnaire interviews with purposively selected key informants such as media trainers, each representing a journalism training institutions in Malawi and 23 systematically sampled journalists, staff assessment, curriculum and document analysis, and literature reviews to identify the characteristics and causes of low quality journalism in Malawi. The data were initially collected in 2008-2009 but updated in 2014 -2015. Typical of grounded theory studies, the data analysis was iterative and recursive (see Yin, 2011) to identify emerging themes.

\section{Discussion}

\section{Nature of programmes}

Curriculum analysis of the journalism education and training programmes and courses in Malawi reveals that in general, the courses offered by the University of Malawi colleges, Luanar, and Blantyre International University attempt to combine practical areas and theory so as to produce a complete and critical journalist. These universities offer typical university four-year bachelor's degrees. Courses offered by the MIJ are mostly short but practical and theoretical. Students graduate with three months' certificates and two-year diplomas. At the Malawi Institute of Journalism, critical thinking, or logic, is not taught. The ABMA journalism training is mostly practical but taught theoretically resulting in graduates knowing but not doing what they know.

Lack of practical or hands on learning in some critical areas at the Malawi Institute of Journalism, in the University of Malawi and Blantyre International University is offset mostly by the brief moments when students go on a three months-long industrial attachment or when they do radio production or TV in groups. Individualised training is impossible because the colleges have very few resources although class sizes (20-45) are reasonable. Malawian journalism education and training institutions fall short of UNESCO criteria. UNESCO (2007) recommends that a typical college and university level journalism education and training programme should:

- Produce graduates who can serve society by informing the public, scrutinizing the way power is exercised, stimulating democratic debate, and in those ways aiding political, economic, social and cultural development.

- Teach students how to identify news and recognize the story in a complex field of fact and opinion, how to conduct journalistic research, and how to write, illustrate, edit and produce material for various media formats (newspapers and magazines, radio and television, and online and multimedia operations) and for their particular audiences

- Give students the knowledge and training to reflect on journalism ethics and best practices in journalism, and on the role of journalism in society, the history of journalism, media 
law, and the political economy of media (including ownership, organization and competition)

- Teach them how to cover political and social issues of particular importance to their own society through courses developed in co-operation with other departments in the college or university.

- Ensure students develop both a broad general knowledge and the foundation of specialized knowledge in a field important to journalism

- Ensure that the students develop - or that they have as a prerequisite - the linguistic ability necessary for journalistic work in their country, including, where this is required, the ability to work in local indigenous or vernacular languages and

- Prepare them to adapt to technological developments and other changes in the news media (UNESCO, 200, p. 6).

To fulfil the above criteria, a training needs qualified staff, adequate teaching and learning equipment and qualified students/

Oral and questionnaire interviews with media trainers, media managers and some journalists revealed that inadequate and irrelevant journalism training is the root cause of poor journalism practice in Malawi. Grey Mang'anda (2008), former Dean of Education and Media Studies at the Malawi Polytechnic, University of Malawi, and the late Edward Chitsulo (2013), former Managing Editor of Malawi's Nation Publications Limited, were critical of the quality of the entrants into these programmes. Mang'anda described the students as "poorly prepared" from secondary schools that are "manned by poorly-motivated teachers" (Mang'anda, 2008). The late Joe Chimwenje, former Theatre and Development senior lecturer at Chancellor College, University of Malawi, was even more critical:

for me an MSCE [Malawi School Certificate of Education, equivalent to "O" level] is not good enough a passport into journalism.... I think degree level qualifications would be the best entry point to enable one to wrestle with the complexities and challenges of rising above the mundane in reporting news; that is, news for both high and low society, news that will challenge and provoke readers into seeing their everyday world from fresh perspectives, and so on...; this cannot easily happen with journalists with a low educational background who are in turn trained through narrow and shallow journalism programmes--the likes that have mushroomed in the country (Chimwenje, 2009).

Chimwenje's (2009) observations resonate with the recommendations of the UNESCO model curricula whose goal "is to form journalists who are in command of the complex skills marking the craft and are also in command of the knowledge and thought to support the reporting and analysis called for in a beat" (UNESCO, 2007, p. 9). This means that journalists need both journalism training to learn skills (such as news writing) as well as journalism education to learn media theories to help them understand and explain social-political complexities of the world (Dube, 2013). Hall (1974) has noted that journalism or media production is not value-free. News values taught today are a reflection of Western society and the media and its journalism. As Louis Althusser has argued (see Hall, 1977), media and journalists act as interpreters of the political-cumsocial world and are conscious or unconscious but subtle ideological state apparatus of control or conveyors of the hegemony and culture of the elite and dominant, the West. Without a national journalism education and training policy to prescribe who gets trained as a journalist and define the broad direction Malawian journalism must take Malawian journalists will never go beyond traditional occidental news values in interpreting events for Malawian society,

The need for a round education has become even more important in the social media era because presently "mainstream" journalists are no longer the primary source of news or interpreters of events since the audience has taken over that responsibility (Picard, 2014; Rosen, 
2011; Bachovska and Pandeva, 2012). This view is also supported by the former Nation Publications Limited managing editor and journalism trainer, Edward Chitsulo (2009). Such critical comments suggest that poor journalism skills do not just originate from the poor and inadequate training in journalism schools, but also from the general poor educational background of those who enrol into journalism training. In sum, the following are among the key background causes of poor journalism according to the media trainers and managers interviewed:

- The poor educational background of those who enrol into the journalism programmes;

- The poor preparation of those who enrol into journalism due to lack of motivation of the teachers in the educational institutions from which those who enrol into journalism training come;

- The general low standards of education in Malawi;

- The uncritical nature of journalism training itself and,

- The narrowness and shallowness of journalism training programmes.

The views of the media trainers are supported by the journalists who went through the training offered by the institutions under review. Asked about what the major causes of poor journalism skills are in Malawi, the 23 journalists who participated in this study listed the following reasons grouped here under three headings:

Table 2: Journalists perceptions of causes of low quality journalism in Malawi

\begin{tabular}{|c|c|c|}
\hline Training & On-the-job & External environment \\
\hline $\begin{array}{l}\text { - Training is short and } \\
\text { inadequate } \\
\text { - Course contents lack depth } \\
\text { - Training is less practical } \\
\text { - Training lacks emphasis } \\
\text { analytical skills } \\
\text { - Little research content in } \\
\text { training } \\
\text { - Too much emphasis on writing } \\
\text { skills for newspapers, thus } \\
\text { limited conceptualization of } \\
\text { journalism } \\
\text { - Proliferation of non-accredited } \\
\text { training institutions } \\
\text { - Training is done by under- } \\
\text { qualified trainers } \\
\text { - Training institutions simply } \\
\text { interested in making money, } \\
\text { hence expensive } \\
\text { - Lack of training equipment and } \\
\text { learning materials } \\
\text { - Absence of tailor-made courses }\end{array}$ & $\begin{array}{l}\text { - Inadequate supervision by } \\
\text { editors and other seniors } \\
\text { - Little on-the-job training } \\
\text { - Internship not adequately } \\
\text { utilised } \\
\text { - Lack of accreditation of } \\
\text { journalists } \\
\text { - Lack of exposure to external } \\
\text { media and other related } \\
\text { institutions both local and } \\
\text { international of ragnition of } \\
\text { - Lack of recognion } \\
\text { creativity junior } \\
\text { professionalism in } \\
\text { personnel } \\
\text { - Where offered, on-the-job- } \\
\text { training applies only to } \\
\text { current position and not for } \\
\text { general future application }\end{array}$ & $\begin{array}{l}\text { - Absence of regulation of media } \\
\text { - Laining institutions } \\
\text { - Lack of vetting of training } \\
\text { institutions and their } \\
\text { qualifications } \\
\text { - No proper coordination } \\
\text { between training institutions and } \\
\text { media houses } \\
\text { - Interference by politicians and } \\
\text { media house owners in the work } \\
\text { - of journalists } \\
\text { - Declining educational standards } \\
\text { - Questionable credibility of some } \\
\text { - Joumining boards } \\
\text { profession of failures and drop- } \\
\text { - Souts } \\
\text { - Some enter journalism not for } \\
\text { they are "stranded" }\end{array}$ \\
\hline
\end{tabular}

Source: Chirwa and Manda 2009

The journalist interviewees at least mentioned the inadequacy of the training offered, its substandard nature, the under-qualification of trainers, the inadequacy of the training contents, and the proliferation of the non-accredited and sub-standard institutions that produce sub-standard journalists as causes of today's substandard journalism practice. The above account, therefore, suggests that, related to training, poor professional skills in Malawian journalists originate from the 
limited nature and gaps in the training these students receive, the poor quality of the training institutions, the under-qualification of the trainers, and the inadequacy of training and learning equipment.

\section{Staff and student profiles}

An examination of the staffing levels of the institutions that train journalists in Malawi reveals that the programmes are minimally staffed if comparisons are made with other universities and training institutions, such as Rhodes University, University of Nairobi, and the University of Cape Town, in the Sub-Saharan region. At the Polytechnic, University of Malawi, for instance, the core staff of the Bachelor of Journalism programme comprised two (2) PhD, seven (7) Master's degree holders, and six (6) first degree holders, five of whom have recently attempted Master's level studies. Except for two, the teaching staff on the BAJ programme have had some experience as radio, television and print media journalists. Thus, this staffing level may be adequate in imparting such practical journalistic skills as news writing, reporting, editing, photography, page design, script writing, and radio/TV production and presentation. However, in terms of journalism education, which ought to concentrate on theories of communication and, media, ethics, and journalism, the programme is understaffed. This staffing inadequacy is exacerbated by virtual lack of interdepartmental, intra-faculty and inter-college exchange of faculty within the University of Malawi to handle some topics/subjects and thus enrich the programmes. Almost all courses on the BAJ programme are handled by departmental staff, some of whom are not fully qualified to handle the courses they teach. At the Blantyre International University (BIU), the staffing situation was even worse. At the time of this study, the programme was taught by one $(\mathrm{PhD})$, (4) four Master's, and three Bachelor's degree holders. At least, unlike at the Polytechnic, the BIU programme benefitted from interfaculty staff exchange.

In terms of student recruitment, the Polytechnic of the University of Malawi is the strictest of all colleges that offer journalism education and training since students are officially selected based on their aggregate score at MSCE (O-level). They must have at least six credits, with English being mandatory, at that level and must pass a University Entrance Examination-to qualify for entry into any university programme. All those selected to the University of Malawi programmes, including the media-related ones, meet this qualification. However, the recruitment of students at the private colleges is mainly determined by ability to pay for courses; and very little on academic qualifications. The professional training standards in these institutions are thus undeniably compromised. This is a rather worrying situation given that these institutions graduate fairly large numbers of those who enter the journalism profession.

At the time of data collection, there were fourteen teachers handling the certificate and diploma programmes at MIJ; eight of these come from the Faculty of Language and Communication Studies and others from the Faculty of Commerce at the Malawi Polytechnic. Interestingly, none of the adjunct teaching staff at the MIJ comes from the Department of Journalism and Media Studies at the Malawi Polytechnic, University of Malawi, which department is supposed to work with the MIJ more closely. Much as these Faculty of Language and Communication Studies teachers are adequately qualified in their respective fields, they would be regarded as under qualified to teach journalism education courses. A national journalism education and training policy would regulate the situation.

\section{Content and journalism training challenges}

Schools of journalism in Malawi use a variety of curricula. The Polytechnic of the University of Malawi started offering the Bachelor of Arts degree in 1999. Its first crop of graduates came out in 2003. Since that time every year an average of 40 graduates in journalism have been added to the industry. By the time they graduate the students mostly learn news-writing and reporting, media criticism, development communication, investigative journalism, communication theory, media law and ethics, radio and TV production, desktop publishing, research project, computer 
aided research, statistics, advertising and public relations, history and sociology. The students spend the second semester (typically three months) in the third year on industrial attachment to media houses and related institutions in the industry. The Malawi Polytechnic programme was reviewed in 2008 and logic and critical thinking, business and economics, and cultural studies were added. The review was an acknowledgement that journalism education and training had shortcomings. It needs to teach facts; citizenship; analytical skills and philosophical values (Robinson, 1988) in addition to traditional skills such as news gathering and writing/presentation. However, even this review left out critical content areas, such as data, health, social accountability, and science journalism, which the UNESCO justifiably recommends (see UNESCO, 2007; 2013). Until recently, agriculture journalism was not prioritised although Malawi has been a predominantly agricultural economy since independence from Britain in 1964 (Kabuye and Mhango, 2006; FAO, 2015). In the area of citizenship and philosophical values, African uMunthu/uBuntu, which would serve the future journalists to understand and properly interpret Malawi's social-political values (See Musopole, 1994; Mbiti, 1991) does not feature anywhere, except when it is minimally integrated into Afriethics, a deontological theory of African journalism ethics proposed by the late Francis Kasoma of the University of Zambia (Kasoma, 1996). Studies indicate that worldwide journalistic globalism is being replaced by localism (see Mending and Franklin, 2011). Another critical course that no college offers is translation, which skill is key because essentially interviews with rural Malawians are in local languages and are translated into English for the newspapers and radio/TV stations that publish or broadcast in English. Many times sources complain about being misquoted, largely due to translation problems.

The Malawi Institute of Journalism (MIJ), which was created to offer short practical courses and to arrange in-house training for journalists and media houses, changed its courses in 1999 and started offering academic diplomas that, on the positive note, have helped its graduates obtain admission into the BAJ programme at the Malawi Polytechnic, University of Malawi. The switch, however, has had a serious impact on the original intent of providing short courses as the Institute for the Advancement of Journalism (IAJ) in South Africa used to do. At the certificate level, the MIJ offers news-writing and reporting, grammar of news discourse, ethics and media law, word processing skills, and broadcast journalism. At the diploma level, the same subjects are offered although in some cases names are changed. For example, News-writing becomes Feature Writing. Other key subjects include Communication Theory and Practice, History of Central Africa and the World, Religions of the World, Human Rights Reporting, HIV and AIDS reporting, Research Skills for Journalists, and Desktop Publishing. However, the Research Methods module has since been removed, implying that research methods is not appropriate at the certificate and diploma levels. The teaching of research methods, newsgathering, logic and critical thinking as separate and unlinked modules misses the opportunity for cross fertilisation of courses for the future journalists to understand the linkages among the several journalistic skills.

The MIJ has a running radio station whose production studios are used by its students for experiential learning. But one of its challenges is that against a total population of 300 certificate and diploma students, it has only five computers for DTP. Technically every computer is a mobile video and audio editing suite but this is impossible to achieve in such a ratio (1 computer: 60 students). Such a technology handicap results in students graduating with limited professional and technical skills. In conjunction with a NGO working the Lower Shire districts of Chikwawa and Nsanje, the Polytechnic has established a community radio station whose impact on student practical learning is yet to be assessed.

None of the journalism education and training institutions has a student newspaper. This means that the students at these institutions have to wait until the second semester of the third year for them to start practising print journalism. As such, it would be farfetched to expect graduates from such institutions to excel on their first appoint in a newspaper environment. 


\section{Gaps in curricula}

In reviewing the programme, the curriculum reform committee decided to remove Research Methods and Research Project from the "old" curriculum as a way of improving it (Pasanje, 2008). It was also done as a way of conforming to the University of Malawi requirement that the MIJ diploma be for two years and not one. The removal of the research-related courses left the students with the possibility of graduating without much understanding of research concepts and research skills that they would need in investigating and analysing events. The practical course on research skills is, therefore, taken against a weak theoretical and conceptual background in research issues. The result is that what is supposed to be a practical course ends up being taught and learnt as a theoretical one.

The other journalism schools, including the Blantyre Business College, Skyway University and many others across the country, use the ABMA Diploma in Professional Journalism curriculum which offers news writing and reporting. It offers three six-month diplomas. Diploma 1 consists of Press and Broadcasting Journalism; Public Relations and Personnel Administration, Business Communication and Environment, Reporting and Editing ${ }^{4}$. While ABMA examines, the local centres teach. The problem is that the quality of the trainers is questionable. While MIJ benefits from the expertise of Malawi Polytechnic lecturers and media experts, the other schools go for the cheapest tutors, including students from the Polytechnic. In one such training college a student doubled as student and teacher. These schools have very little in terms of equipment for Radio and TV broadcast production but students get qualifications in such subjects. An editor at one of the radio stations expressed disappointment at seeing someone with a seemingly good foreign certificate but could not identify any keys on the console and understood no audio editing software. "Much as we wanted to employ her, we had to leave her" (Zawanda, 2008).

While academics and former students alike blame the quality of the training, its content and duration inadequacy of the same, both seem to forget that the packaging of courses may also be another major cause. Journalism requires development of linkages between events. This can only be achieved through the "metissage" of writing and production skills with knowledge of other areas. As such, courses like communication for development, communication theory, rural development and economics, which are in some cases taught as standalone modules, should in fact be packaged as one to provide not only a strongly theoretical foundation but also practical applications. The same applies to stand alone modules or courses such as logic and critical thinking, research, news gathering (including interviewing), and investigative journalism, which should be handled as one so that students appreciate the need to plan, create objectives for their stories before designing the questions and conducting the interviews and library research. During the writing process, logic and critical thinking are important because they help journalists to build coherent and fact-supported arguments and to present an investigative, feature story or documentary in a logical manner. Creative writing and feature writing have more similarities than differences; yet in journalism education and training these are taught separately or in some cases, creative writing is never taught at all although literature is a common feature on journalism education and training curricula. Because of their lack of focus on or being grounded in local situations, social foundations and life philosophies, as Kwame Nkrumah, Julius Nyerere and Francis Kasoma proposed journalism should (see Skjerdal, 2012), the journalism curricula have very little focus on development discourses, policies and programmes, a point which Wimmer and Wolf (2005) also noted in their analysis of 19 journalism education and training institutions in Africa. The BA (media for development) and BSc (agricultural development communication) are the only exceptions, which is surprising for a developing country.

In short, courses need to be properly thought out, appropriately sequenced, and adequately funded and staffed to achieve the long-term objective of producing analytical journalists. As Wimmer and Wolf (2005) have hinted, there is a causal relationship between journalists' performance and how/what they are taught. 


\section{On the job training}

There are differences of opinion between the editors and the lower-ranking journalists on the existence of on-the-job training in the media houses. The editors maintain that they offer the training, while the journalists argue that such a thing does not exist. The editors' view is supported by some media trainers who indicated that they have ever offered on-the-job training for some media houses, but the details of such training were not provided. The views of the journalists suggest that formal on-the-job training sessions are virtually non-existent in most, if not all Malawian newsrooms. Editors, however, have among their key roles, the one-on-one coaching of reporters. This is often ignored. The process is done as a daily procedure whereby what goes into the day's pages or bulletins is determined during morning meetings. All journalists are asked to come up with possible news stories. These are discussed, possible sources identified and tips shared before reporters are deployed to gather the news. When the reporters get back, often around noon, they concentrate on writing, verifying information over the phone, the internet and with colleagues inside and outside the newsroom. When the story is finished, it is passed to a section sub-editor or editor before it gets to the issue editor for checking for possible ethical and legal pitfalls, thoroughness, language and grammar correctness and house-style. Beyond this usual rigmarole, nothing of on the-job-training exists. This view was supported by Chimwenje (2009), who admitted that while on-the-job training existed in media houses but doubted the systematic nature of such an initiative:

Unless things have now changed. It is usually the "senior" staff within the media houses that provide on-the-job training. During my time more than ten years ago, you were just thrown in into the thick of things as a cub reporter and you would learn the ropes of the trade as your sub-editor loudly threatened to spike your story. It wasn't really training as such. I would call it some kind of boot-camp training. Of course, there were times depending on the personalities one was working with where some kind of mentoring was taking place. I am not certain if there are formal training departments in the media houses now, but I really doubt it (Chimwenje, 2009).

Chitsulo (2009) observed that Nation Publications Limited intended to roll-out systematic inhouse training in 2009, which in a way was a tacit admission that NPL did not have it in a systematic manner. Five years later, Chitsulo (2014) reported that all new recruits at NPL undergo some form of training and orientation so that they become multi-skilled and multipurpose reporters. Multiskilling and critical or analytical thinking is sine qua non for a $21^{\text {st }}$ century journalist but to what extent this is a general feature of the Malawian media house is something for another study. One editor asked why he should be teaching people who have graduated in journalism. His expectation was that a graduate in journalism would come and immediately start doing journalism.

\section{Contribution of external media institutions}

Since 1994, there has been no dearth of short training courses for Malawian journalists. For example, for quite some time the Maputo Based NSJ Centre offered three-week courses in rural reporting, basic news writing, feature writing, sports reporting, court reporting, economics and business reporting, among others. Another prominent media training institution has been the Media Institute of Southern Africa (MISA) with funding from NiZA of the Netherlands and other funding agencies, which has trained Malawian journalists in several areas of specialization including media ethics and the law. Like SAHRIT before it, Casals and Associates of the United States trained Malawian journalists in media and corruption with funding from USAID. FOJO, also of the Netherlands, has been involved in the training of media trainers in the southern Africa region. Most Malawian trainers have passed through one of the FOJO courses. The World Bank and the Canadian International Development Agency (CIDA) have trained journalists in business and 
national budget analysis. Panos Southern Africa has conducted training on reporting research and offered scholarships for writing development features. Some UN agencies have conducted training sessions for media personnel in specialized areas of HIV and AIDS, and Children's Rights. GIZ of Germany has been involved in training of journalists, mostly in the field of peace and conflict reporting, and in aspects of decentralization. Prior to the establishment of Television Malawi, future broadcasters, engineers, and others were trained by the Namibia Broadcasting Corporation (NBC) among others. Since 2004, the CBA, in partnership with the Malawi Electoral Commission, has trained stringers to beef up the existing corps of journalists to ensure media coverage during elections.

These short courses have, in some areas, resulted in some noticeable improvements but in general the quality of news reporting and analysis is low. Those who have gone through such training sessions observed that the time allocated was often "too short" to adequately cover the material offered. There were "many modules [or topics] to be covered" but the duration of the training session was not adequate (Ndebvu, 2009). In some cases, the training was offered by people, who though qualified, had little knowledge of the Malawi situation and what obtained on the ground and hence could not make reference to practical local situations. However, the training offered good exposure to current issues in journalism, use of cutting edge technology, day-to-day practical skills, specific sector training, and networking with other people beyond the confines of one's newsroom environment.

A noticeable feature of these courses is that they are not systematically evaluated. This study did not come across any evaluation of the courses mentioned above. It becomes difficult, therefore, to cite their impact on journalists in Malawi. In the absence of a robust evaluation, it is difficult to design follow-up interventions that would build on and go beyond what has already been offered. There is also a real possibility that these courses are offered to the same people over and over and thus not widely spreading the process of skills acquisition.

\section{Conclusion}

The findings of this study indicate that much as poor student educational background, under qualification of teaching staff, understaffing of programmes and inadequate training may be the major causes of lack of professional skills among Malawian journalists, there are other equally important factors that hinder the development of professional skills among journalists in Malawi. These include limited funding; limited space for interaction between journalists and researchers; inappropriate content sequencing in training curricula and above all lack of a journalism education, training and media development policy contribute to the lacklustre performance of journalism graduates when they join the industry. However, priority should be on addressing the challenges related to the identified gaps in the training curricula, research skills acquisition, the need for a college and university level education and training in journalism that is "responsive to the needs of Malawi and the world" (Malawi Government, 1998b). To achieve this, there is need for the realignment of existing communication and education policies to clearly stipulate what should be taught in journalism education and training. This will help the future journalists to understand and appropriately interpret what constitutes local media content as the communication act prescribes (Malawi Government, 2016). As Hume (2007) and Berger and Matras (2007) recommend, university education and training of journalists should involve partnerships with the media industry, UN organizations, and NGOs, to regulate content and fund training of staff, programmes and procurement of teaching materials to realize the dream of quality journalism. The starting point for developing a national journalism education and training policy for Malawi is the Paris Declaration on Media Education of 2007 (UNESCO, 2007b). A national policy on journalism education and training will ensure that Malawian journalism does not "exist independent of [Malawian] community" (Deuze, 2006, p.25). 


\section{Acknowledgments}

The statistical and verbal data reported in this paper were collected and recorded in 2008-2009 and updated in 2014-2015 by the author. The author acknowledges the financial support of the now defunct PANOS London for the initial study and the historical review by Professor Wiseman Chijere Chirwa of Chancellor College, University of Malawi.

\section{References}

Article 19. (2000). At the Crossroads: Freedom of Expression in Malawi. The final Report of the 1999 Article 19 Malawi Election Media Monitoring Project. London: Article 19. http://www.article19.org/data/files/pdfs/publications/malawi-at-the-crossroads.pdf. (Accessed 9 September, 2014).

Bachovska, J. \& Pandeva, I.R. (2012). The Future of Journalism Education: Challenges and Prospects. Iustinianus Primus Law Review, 3(2), pp. 1-14.

Berger, G. \& Matras, C. (2007). Criteria and Indicators for Quality Journalism Training Institutions and Identifying potential Centres of Excellence in Journalism Training in Africa. Paris: UNESCO. http://www.unesco.org/webworld/en/african-journalism-schools-report. (Accessed 11 December, 2014).

Chimwenje, J. (2009). Personal Communication (17 January).

Chirwa, W.C. \& Manda, L.Z. (2009). Unpacking Challenges in the Field of Research Communications: Media development, content and quality of media training in Malawi. Unpublished field research. London: Panos London.

Chitsulo, E., (2014). Personal Communication (12 October).

Chitsulo, E., (2009). Personal Communication (13 January).

Chitsulo, E. \& Mang'anda, G. (2011). Origins, development, and management of the newspaper industry in Malawi. In Kondowe, E, Kishindo, P., \& Mkandawire, F (eds.), Journalism Practice in Malawi: History, Progress and Prospects. Lilongwe: UNESCO Malawi Commission (pp.1-14).

Chitsulo, E. (2015). Journalists as watchdogs of good governance: Challenges and some ways forward. Speech made at the $16^{\text {th }}$ graduation ceremony of the Malawi Institute of Journalism, November 28, 2013. Journal of Development and communication Studies, 4(1), pp. 62-65. http://www.devcomsjournalmw.org/paper-author/edward-chitsulo. (Accessed 17 June, 2015).

Deuze, M. 2006). Global Journalism Education: A Conceptual Approach. Journalism Studies, Vol. 7 (1), pp.20-34 https://www.tandfonline.com/doi/abs/10.1080/14616700500450293. Accessed 24 May 2015.

Dube, B. (2013). Challenges for Journalism Education and Training in a Transforming Society: A Case Study of Three Selected Institutions in Post-1994 South Africa. PhD Thesis, Faculty of Arts and Social Sciences, Stellenbosch University. $\quad$ http://www.genderlinks.org.za/attachment.php?aa id=18103. (Accessed 10 September, 2014).

Food and Agriculture Organization (FAO). (2015). Country fact sheet on food and agriculture policy trends: Socio-economic context and role of agriculture. Rome: FAO. http://www.fao.org/3/a-i4491e.pdf. (Accessed 23 June 2018). 
Hall, M.\& Ham, M. (1994). Economics of Press Freedom and Media Development in Malawi. In Media for Democracy in Malawi: Report of a conference convened by the International Federation of Journalists, Blantyre, 17-19 Aug. 1994.

Hall, S. (1974). Encoding and Decoding in the TV Discourse. http://merz.akademie.de/ stephen-gregory.texte. (Accessed 20 October 2014).

Hall, S. 1977. Culture, the Media and the 'Ideological Effect'. In Curran, J., Gurevitch, M. and Woollacott J. (eds.) Mass Communication and Society. London: Edward Arnold (pp. 315-348).

Hume, E. (2007). University Journalism Education: A Global Challenge. Washington: Centre for International Media Assistance/National Endowment for Democracy.

Ifex. (2002). Regulatory authority back-pedals on threat to radio station. https://www.ifex.org/malawi/2002/07/05/regulatory authority back pedals/. (Accessed 3 May 2015).

Institute for War and Peace Reporting (IWPR). (2014). Malawi Election Monitoring. https://iwpr.net/what-we-do/printed-materials/malawi-election-monitoring. (Accessed 23 June 2015).

Italiander, R. (1961). The New Leaders of Africa. New Jersey: Prentice-Hall.

Kabuye, E.S. \& Mhango, J.A. (2006). A Brief History of Agricultural Extension Services in Malawi from 1948 to 2000. Lilongwe: Ministry of Agriculture.

Kasoma, F. (1996). The Foundations of African Ethics (Afriethics) and the Professional Practice of Journalism: The Case for Society-Centred Media Morality. Africa Media Review, Vol. 10(3). pp. 93-116

Kvale, S. (1996). InterViews: An Introduction to Qualitative Research Interviewing. London: SAGE.

Malawi Communications Regulatory Authority (MACRA). (2014). List of Broadcasting Licensees. http://www.macra.org.mw/downloads/Licenses/Broadcasting.pdf. (Accessed 10 October, 2014).

Malawi Government. (1998). Communications 1998. http://www.wipo.int/wipolex/en/text.jsp?file id=222361. (Accessed 24 June 2015).

Malawi Government. (1998b). University of Malawi Act.

Malawi Government. (2016). Communications Act, 2016. (Accessed 24 August, 2017).

Manda, L.Z. (2004). Covering the elections: the role of the media. In Ott, M, Immink, B, Mhango, B, \& Peters-Berries (eds.). Power of the Vote: Malawi's 2004 Parliamentary Elections (pp. 159-180). Zomba: Kachere

Manda, L.Z, Nyirenda, N. \& Tsitsi, C. (2017). Journalists in Malawi. http://epub.ub.unimuenchen.de/34880/1/ counytry report Malawi.pdf.

Mang'anda, G. (2008). Personal communication/questionnaire response (November 26) 
Manjawira, E. \& Mitunda, P. (2011). Origin, growth and development of the broadcasting industry in Malawi. In Kondowe, E, Kishindo, P., \& Mkandawire, F (eds.), Journalism Practice in Malawi: History, Progress and Prospects. Lilongwe: UNESCO Malawi Commission (pp. 15-33).

Mbiti, J.S. (1991). Introduction to African Religion. Oxford: Heinemann Educational Publishers.

Musopole, A. (1994). Being buman in Africa. New York: Peter Lang,

Ndebvu, H. (2009). Personal Communication (12 January).

Pasanje, E. (2008). Personal Communication/interview (December 15).

Picard, R.G. (2014). Deficient tutelage: Challenges of contemporary journalism education. Keynote address to the Toward 2020: New Directions in Journalism Education Conference, Ryerson University, Toronto, May 2014. http://www.robertpicard.net/files/Picard deficient tutelage.pdf. (Accessed 5 October, 2014).

Robinson, M.J. (1988). The Media as a curriculum. In Berger, A. Media USA: Process and Effect. London: Longman. pp. 31- 43

Rosen, J. (2011). The People Formerly Known as the Audience. http://www.huffingtonpost.com/jay-rosen/the-people-formerly-known 1 b 24113.html. (Accessed 10 October, 2014).

Ross, A. (1996). Blantyre Mission and the Making of Modern Malawi. Blantyre: CLAIM

Rotberg, R. (2002). Hero of the Nation: Chipembere of Malawi: An Autobiography. Zomba: Kachere.

Sembereka, G.M. (1980). Early Newspapers and the Shaping of Official Policy in Nyasaland, 18841914. Zomba: Chancellor College (Unpublished Fourth Year History Research Seminar Paper).

Skjerdal, T.S. (2012). The three alternative journalisms of Africa, International Communication Gazette, $\quad 74 \quad$ (7), pp. 636-654. https://www.academia.edu/2012635/The three alternative journalisms of Africa. (Accessed 20 October, 2014).

UNESCO. (2007). Model Curricula for Journalism Education for Developing Countries and Emerging Democracies. Paris: UNESCO.

UNESCO. (2007b). Paris Agenda or 12 Recommendations for Media Education. www.diplomatie.gouv.fr (Accessed 11 November 2015).

UNESCO. (2013). Model Curricula for Journalism Education: A Compendium of New Syllabi. Paris: UNESCO

Wimmer, J. \& Wolf, S. (2005). Development journalism out of date? An analysis of its significance in journalism education at African universities. http://epub.ub.unimuenchen.de/647/1/mbk 3.pdf. (Accessed 22 October, 2014).

Yin, R. (2011). Qualitative Research from Start to Finish. New York: The Guilford Press.

Zawanda, L. (2008). Station Manager, Joy Radio, Personal Communication (November 27). 


\section{End notes}

\footnotetext{
${ }^{1}$ See freewebs.com/linjem/unimadevcomdegree.htm

${ }^{2}$ The course is taught over a 13-week semester (approximately 39 hours including examination, contact hour and tutorial periods). Communication for development and Investigative journalism require both theoretical knowledge and practice. The 13 weeks that are dedicated to each of these courses are not adequate.

${ }^{3}$ See http://www.abma.uk.com

${ }^{4}$ For the rest of the content, see http://www.abma.uk.com/samplepapaer.asp
} 